\title{
Lexis
}

Journal in English Lexicology

$15 \mid 2020$

The adjective category in English

\section{Adjectives or Verbs? The Case of Deverbal Adjectives in -ED}

Jean Albrespit

\section{(2) OpenEdition}

1 Journals

\section{Electronic version}

URL: http://journals.openedition.org/lexis/4146

DOI: $10.4000 /$ lexis. 4146

ISSN: 1951-6215

\section{Publisher}

Université Jean Moulin - Lyon 3

\section{Electronic reference}

Jean Albrespit, «Adjectives or Verbs? The Case of Deverbal Adjectives in -ED », Lexis [Online], 15। 2020, Online since 13 June 2020, connection on 17 December 2020. URL : http:// journals.openedition.org/lexis/4146; DOI : https://doi.org/10.4000/lexis.4146

This text was automatically generated on 17 December 2020.

\section{(c) (i) (9)}

Lexis is licensed under a Creative Commons Attribution-NonCommercial-NoDerivatives 4.0 International License. 


\title{
Adjectives or Verbs? The Case of Deverbal Adjectives in -ED
}

\author{
Jean Albrespit
}

\section{Introduction ${ }^{1}$}

1 Adjectives form a category which is notoriously difficult to define as it has "potentially boundless membership" [Givón 1970: 816]. Furthermore, as Givón [1970: 816] observes, "the great bulk [of adjectives] are morphologically derived from either nouns or verbs." This article will focus on one of the possible ways of creating an adjective, i.e. by using a verb and more specifically the past participle of a verb, as in, for instance:

(1) The courtyard was bounded by a range of cloisters two storeys high (William Dalrymple, City of Djinns, 1993, BNC).

2 Adjectives formed in this way are not the result of a straightforward case of derivation (due to the fact that -ED can be both an inflectional suffix and a derivational suffix): an ambiguity often remains as to the status of the V-ED form (-ED will stand for "past participle"), between adjective and verb, especially where adjectival passives are concerned (Bolinger [1967]; Wasow [1977]; Levin \& Rappaport [1986]; Grimshaw \& Vikner [1993]; Ackerman \& Goldberg [1996], [2001]; Kibort [2005]; Lundquist [2013]; McIntyre [2013]; Bruening [2014]). Such terminology as "adjective-like", "participial adjectives" (Quirk et al. [1985: 168]; Huddleston \& Pullum [2002: 78]), or, more rarely in the description of English, "verbal adjectives", is a sign of the difficulty of identifying what appears to be a hybrid form. It has been pointed out (Oltra-Massuet [2014: 8]) that deverbal adjectives raise problems of morphology, syntax and semantics. The word brown, for example, when taken in isolation, can be an adjective or, in specialised contexts, a verb or a noun obtained by conversion. The past participle of the verb in the following recipe can be interpreted as indicating a state which is reached and therefore as having acquired an adjectival status: 
(2) Turn them all evenly 2 or 3 times until nicely browned all over. (www.theguardian.com/lifeandstyle/wordofmouth/2013/jan/17/how-tocook-perfect-sauteed-potatoes) adjectives (by "stabilise", we refer to referential stabilisation, which means that the newly-formed adjective is easily understandable by a co-speaker and that the cospeaker can associate a reference to the lexeme without ambiguity or too great a cognitive effort). There seems to be no systematic, clear-cut distinction between states and resultant states ${ }^{3}$. Let us consider two sentences:

(a) The door was lined with metal

(b) The door was locked.

In the first sentence, with "lined", the stabilisation is complete and there is no reference to a change of state, whereas with "locked" in sentence (b), the deriving verb can be reactivated (especially since the process lock implies a doer and thus intentionality), as can be shown by adding an adverb - "the door was suddenly locked" -, as in the following example:

(4) I had been sitting in the room for only a moment when the door was suddenly locked from the outside. (Tan Malaka, From Jail to Jail, Ohio University, 1994)

6 Although most occurrences of adjectival participles are part of passive constructions, it has been noted (Kibort [2005]) that derivational adjectives are independent of passivisation, which means that they can occur in various contexts which will be examined below. Throughout this study adjectival participles will be referred to as "V-ED adjectives".

7 If the V-ED structure has been studied extensively in relation to its hypothesized adjectival features, less attention has been paid to discursive strategies and pragmatic parameters. One of the aims of this article is to take context into account, not just isolated forms. The present study is based on written and spoken corpora (BNC, COCA and a web search). The parameters surveyed are:

- the lexical aspect of the verb

- agentivity (recoverable or not)

- prefixing (for instance the prefix be-in bedecked or the negative prefix un-in unchecked)

- lexicalization (particularly the contribution of the noun in a collocation of the type abandoned child)

- syntax (attributive or predicative position, the possibility of preposing or postposing, complementation, as in: But Mr. Lorette seemed possessed of a miraculous talent (Fiona Davis, The Masterpiece); Pietro Miletti appeared, his elegant shoes and trousers bespattered with mud (BNC)).

8 The conclusion which is reached is that instability is inherent to the use of V-ED adjectives as any variation (the presence of an adverb for example) can change the 
interpretation. The process of stabilisation is seen as linked to two major parameters: the suppression of the origin of the potential change of state (and the absence of telicity) and the backgrounding of agentivity.

\section{Defining adjectives}

Before examining the more or less stative nature of V-EDs, it will be useful to provide a brief review of the criteria defined in reference grammars to decide if a word belongs to the class of adjectives.

Quirk et al [1985: 404] distinguish between "central" and "peripheral" adjectives. Central adjectives display a set of properties: they can occur in an attributive position or a predicative function after the copula seem, can be premodified by very and can be used as a comparative. They semantically denote a property of the noun. In the same vein, Huddleston \& Pullum, [2002:528] mention "central members of the adjective category" as having a "cluster of syntactic properties": they can appear in three main functions - attributive, predicative and postpositive, are gradable and have inflectional or analytic comparatives and superlatives -, and "characteristically take adverbs as modifiers (remarkably happy, surprisingly good)". As Bolinger [1967: 2-3] observes, "there are many attributive adjectives that are never predicative" but "fewer of them that are predicative but seldom or never attributive". Therefore, the possibility of a V-ED form occurring in an attributive position is a robust test for determining its adjectival quality. Hence the example a fallen leaf, where "fallen" refers to the result of an action and consequently to a state. When does a V-ED become an adjective? This is an issue that will be addressed in this study. Apart from making a terminological point, determining the adjectival character of a V-ED appears crucial in assessing the role it plays in the information structure.

\section{A typology of deverbal adjectives in -ED}

11 In this section, the growing degree of "stativeness" and therefore of "adjectiveness" is examined, starting with lexicalised forms and moving on to the role of affixation and lastly syntax.

\subsection{Lexicalised V-EDs and loan words}

12 It is a well-known fact that the morph -ED possibly represents three suffixes which have merged: the verbal suffix of the past participle, the suffix -ED deriving adjectives from nouns (from Old English -ede $e^{4}$ ) and the suffix -ED "added to adapted forms of Latin participles, the intention being to assimilate these words in form to the native words which they resembled in function" (OED). There is only a small class of such adjectives, some of them being obsolete (acquisited) or technical (versed, a word used in trigonometry). They are fossilised forms of the type situated:

(5) Situated learning emphasizes the context and application and use of knowledge. (https://sites.google.com/site/socialapproachestolearning)

(6a) Penns Hall is situated just 6 miles from the centre of Birmingham. (BNC) 
13 Although they are not central adjectives (Quirk et al. [1985: 404]) as they cannot be premodified by very (*very situated) and cannot be used in the comparative (*more/*most situated), they have at least the adjectival property of being statives. No underlying process can be retrieved:

(6b) *Penns Hall is suddenly situated just 6 miles from the centre of Birmingham.

14 In (7), detached can be construed as the result of an action made by an agent or at least an "agent of result5" (Bolinger [1972: 201]) or, as in (8), a state which does not result from a previous action:

(7) Control knobs may be detached and placed in the fryer basket for soaking. (Rae North, Cleaning Professional Kitchens, 1985, BNC)

(8) Across the road was a detached house - white, marbled, single-storeyed, with a pool and a $6 \mathrm{ft}-$ high wall. (The Daily Mirror, 1992, BNC)

There is therefore no ambiguity as to the adjectival status of V-EDs belonging to this class.

A marginal category of V-EDs comprises "double" past participles in French loanwords, such as appliqueed and sautéed. These words are used almost exclusively in an attributive position (appliqueed tea towels, sautéed potatoes), in an adjectival function, and rarely as verbs. In (9) the author does use sautée as a verb in an article comprising many words borrowed from French, so this could be due to stylistic variation:

(9) Anthony Bourdain sautees his potatoes in bacon fat, rendered from lardons cooked alongside the spuds. (www.theguardian.com/lifeandstyle/ wordofmouth/2013/jan/17/how-to-cook-perfect-sauteed-potatoes)

Lastly, a number of V-EDs are fully lexicalized as adjectives: addled, bewildered, elated, cadenced (perhaps derived from the noun cadence), confused, disgruntled, embarrassed, excited, muddled, perplexed, and even though a corresponding verb still exists, all relation to the verb has been severed. A subcategory of verbs prefixed with un- (unfettered, undaunted, unabashed, unscathed) or dis- (disconcerted, discomfited, disordered) no longer has an active relation with the verb it is derived from.

\subsection{Affixed V-EDs}

17 Some prefixes and suffixes are determining factors in the acceptability of a V-ED in attributive position.

\subsection{1. un-V-ED}

18 The negative prefix un- is by far the most productive prefix: the V-EDs unchecked, unattached, uncommitted, unbuilt, undrunk, uneaten, etc. can all freely fill a prenominal slot when non-derived verbs cannot systematically occupy a prenominal position:

(10) Why can't every child have the same worth as a human? When an unliked child grows up, how is he or she going to treat people? (https:// divorcedmoms.com/the-favorite-child-vs-the-unliked-child/) 

therefore, there can be no ambiguity as to its adjectival function:

(12) Moreover the baked bread tends to collapse on cooling or to be uncooked in the centre. (New Scientist, BNC)

Be can be identified as a copulative verb only, not as an auxiliary of the passive. However, it is to be noted that new uses can be licenced especially in specialised contexts: for instance, the verb unlike is a feature of Facebook and on sites like Research Gate, it is possible to unfollow:

(13) It's hard on the ego, being gradually unfollowed by 24 million people over the course of several years. (www.theguardian.com/commentisfree/ 2013/jan/27/justin-bieber-pop-idols-never-die)

The function of un- + V-ED will be further studied in section 3.

\subsection{2. be-V-ED and re-V-ED}

Verbs derived from nouns by way of the prefix be- and in the past participle: bedecked, beloved, bejeweled, bespectacled, besmeared, bemused, bespattered, bewitched, etc. are good candidates for the attributive position:

(14) Leonard was up, standing his ground, his arms folded across the bespattered apron. (Ron Carlson, Truants, 1981)

When there are two different forms - loved and beloved -, the derived form in be-can be used as an adjective without any syntactic restriction:

(15) Young is up by 10 am for breakfast with his wife and three children: two teenage boys and Hannah Harley, four, named after his beloved motorbike. (Daily Telegraph, BNC)

(16) R. rubrifolia is the rose much beloved by flower arrangers for the copper-mauve foliage. (Bill Swain, Roses: Questions and Answers, 1990, BNC)

(17) The question What is History? beloved of university examiners, has no definitive answer. (Climber and Hill Walker, 1992, BNC)

Beloved is attested in attributive and predicative positions, in the comparative and superlative. It is also attested in the long passive, complemented by a by-prepositional phrase (16) or a prepositional phrase introduced by of (17), showing a somewhat fuzzy perception of its status, between adjective and verb. The suffix -ED, contrary to other affixes, does not assign the word it is attached to a definitive class. The verbal function can be activated, even though beloved is generally used as an adjective: there are 745 
occurrences of beloved in the BNC, of which 101 take a complement in of, 35 a complement in by and 35 are nominalised (his/her/their/N's beloved). Loved on the other hand has more restricted uses as an adjective. Apart from the collocation loved ones, there has to be a facilitating context, for example two coordinated adjectives in (18), or, in (19), a "semantic path" leading to the construction liked $N$ (namely a context making the construction immediately understandable):

(18) Most people want to be special and know they are special to their loved and chosen partner. (Janet Mattinson \& Christopher Clulow, Marriage Inside Out, 1989, BNC)

(19) She was raised in north Philadelphia in a loving environment, she says. "I grew up very much a loved child. I know it. My mother (Joyce Scott) loves me. My grandmother (Blue Babe) loves me." (Jet, 2001, COCA)

V-EDs derived with re- can also occur more easily in prenominal position:

(20) They helped dedicate a rebuilt bridge in May, and they bundled up in cold and light rain to watch the Memorial Day parade at month's end. (The Boston Globe, 2017, COCA)

Without the prefix, built cannot occur in (20): ${ }^{*}$ a built bridge. Other examples include: redesigned, reread, rewritten, reopened, etc., although collocations can licence such examples as the written word, certainly by analogy with the spoken word:

(21) For example, with TV came video tapes and with radio a whole new system for sending recordings out using the voice rather than the written word. (Stafford Whiteaker, A Career in Advertising and Public Relations, 1986, $\mathrm{BNC})$

\subsubsection{V-ED + suffix}

Verbs in -ise (GB) / -ize (GB, US), derived from nouns (actualise, Americanise, authorise, localise, personalise, regularise, etc.) can almost systematically be turned into adjectival participles:

(22) We've lost many of our localised products because they've been taken over by multi-nationals. (Northern Echo, BNC)

The suffix has the following meanings (according to the origin of the stem): "to act like, or in accordance with"; "to make (that which is expressed by the derivation)"; "make or conform to, or treat in the way of, the thing expressed by the derivation" (OED). Verbs belonging in this paradigm might then display a set of characteristics sufficient to ensure referential stability.

\subsection{Prenominal vs postnominal V-EDs}

The position relative to the head noun is crucial in determining the degree of stability achieved by V-ED. A prenominal position is the indication of the highest degree of stability:

(23) Well he lo - well he eats eats raw meat. He won't eat cooked meat, her cat won't. (BNC spoken) 
tributive position, the stative interpretation, as will be demonstrated in the following section, depends on several parameters (tense of the verb, short or long passive, semantics of the verb):

(24) "Rare" he calls it, but it looks uncooked to me. (Cecilia Manguerra Brainard, When the Rainbow Goddess Wept, 1999)

(25) When the rice is cooked, gently mix in all other ingredients. (Maggie Humphreys \& Les Snowdon, The Walking Diet, 1991, BNC)

\section{V-ED in attributive position}

\subsection{A criterion for the adjectival quality of V-ED}

31 As has been noted above, one robust criterion in determining the stative and permanent property of a V-ED (and hence its adjectival quality) is the possibility of inserting it in an attributive position:

(26) At this point the young man, who had been reading a folded newspaper, looked up and said in a slightly truculent voice [...] (Barbara Pym, An Unsuitable Attachment, 1993, BNC)

The prenominal position, folded newspaper, can be filled with an adjectival passive participle. The reference to the process fold can be reactivated in a paraphrase: The newspaper had been folded by someone. However, in a folded newspaper, the previous state ("paper not folded") and the change from the previous state to the state at the time of reference is not relevant: it is irrelevant who folded the paper. The property of newspapers to be folded is shared knowledge and therefore is not surprising and does not require any cognitive effort to be understood. On the contrary, the expression a stuck newspaper would be odd, unless a context explains the link between the two notions.

\subsection{Verbs of consumption}

Another class of verbs comprises verbs that indicate that the object has disappeared because of the process denoted by the verb, for instance eat: there are no occurrences of eaten food in the COCA and BNC corpora. Something that is no longer in existence cannot become a theme. A modification through an adverb is required: half-eaten, partially eaten or the affixation of a negative prefix. Consume, a synonym of eat, has a narrower range of uses, in more technical contexts, and can occur in an attributive position, although an adverb - locally in (27) - is almost always required:

(27) It will then be important to gather information on local dietary and agricultural practices and beliefs to assess the feasibility of improving the production, storage, and consumption of local vitamin-A-rich foods, the introduction of new foods, or fortification of a locally consumed food. (The Lancet, 1993, BNC) 


\subsection{Negative prefixes}

As was noted earlier, negative prefixes make the majority of V-EDs acceptable in an attributive position: uneaten food for example. With such past participles as uneaten (28) and undrunk (29), the meaning is that the food or drink is still there and the implication that they are meant to be consumed. In (28), the expression unread scripts does not refer to anything visible; it is a distinctive feature (a script is meant to be read, the state "unread" violates the expectation created by the semantics of the noun):

(28) I can just see them: Mum with a cottage cheese salad lying uneaten on her plate - Dad in the office amid piles of unread scripts, unable to concentrate for fear that his darling? hated? infuriating daughter lies at the bottom of the Thames, the Severn, the Atlantic... (Alison Leonard, GateCrashing the Dream Party, 1990, BNC)

(29) At that time, one could enter the building easily, wander up and down the racked and discoloured ramp, contemplate the looting of one of the door handles, even find undrunk wine in a cupboard. (Royal Institute of British Architects Journal, 1990, BNC)

In (30), the head noun prawn described by unshelled is in its initial state; the negative prefix, however, indicates that it might be otherwise:

(30) I top it with uncooked, unshelled prawns that have been marinated in grated fresh ginger and lime juice. (Daily Telegraph, BNC)

The same goes with other associations: as they are to be expected, they are not worth mentioning. Thus it is not surprising that a hero should be sung, making pointless such a construction as *a sung hero; if the hero is unsung, he acquires a distinctive quality worth mentioning: an unsung hero is acceptable. As will be seen in the study, infelicitous expressions can become possible in a special context, for example when two notions are contrasted:

(31) "It's OK sweetie," she murmured. "You're an unsung hero." "I don't want to be an unsung hero," grumbled Kevin. "I want to be a sung hero. I want to have songs written about me. Grand operas. (John Moore, Heroics for Beginners, 2004)

It seems counter-intuitive that an un-prefixed V-ED should more easily occur in prenominal position as non-existence is by essence not visible. Our hypothesis is that there is an implied relation in should or could. An unbuilt house is a house that should be or could be built. So it follows that there is the evaluation of a distance relative to a norm which is "house = built". An uneaten cake is a cake that is whole and thus in its normal state. However, it should have been eaten: the expectation is flouted - whereas ${ }^{*}$ an eaten cake is no longer a cake. ${ }^{*} A$ read book is also infelicitous as a book which has been read bears no trace of its having been read. An unsold car is a car that has not been sold yet: the distance is temporal in this case.

\subsection{V-ED modified by an adverb}

However, as has also been noted above in this section, modification with an adverb makes possible the use of read as an adjective: 
(32) Visit an area, town or natural location that is featured in a recentlyread book or an upcoming book to be discussed. ( http:// www.thereadingclub.co.uk/bookclubfieldtrips.html)

(33) Howe's history may have been "the most commonly read book" in Ohio "outside the Bible". (Journal of American Culture, 2016, COCA)

(34) He wrote a widely read book about his amazing recovery. (Saturday Evening Post 2008, COCA)

Even then, there are few occurrences of "ADV V-ED book" (only one occurrence in the COCA of each of the following phrases: "recently read book", "most commonly read book", "widely read book" and one occurrence in the BNC of "widely read book". There is no occurrence of "read books" without an adverb.

\subsection{The feature + affected}

The relationship between real-world experience and its linguistic representation (eat a cake, for instance) seems easy to understand. It is less so with verbs that do not denote concrete elements. Let us consider the following expressions: teach a lesson, learn a lesson. There are no occurrences in the COCA and BNC of "det. + taught lesson" or "det. + a learnt lesson".

One solution is to consider the object as affected: it has to be transformed in some way. Indeed, in spilt milk, the object appears in a different state: spilt milk is no longer milk. Fish that has been caught can become caught fish. However, there is no subclass of caught fish, as there is a subclass of salted fish. A context is therefore needed to grant the acceptability of caught fish. A "resultant state" is a better candidate to an adjective status if it is observable. Bolinger [1962: 9] makes the observation that dented bells is fine, but not *rung bells. The mark left on a bell can be seen. As Bolinger [1967: 9] puts it:

The typical perfect participle that can be used attributively is one that leaves a mark on something.

He goes on to oppose a scratched surface to *a scratched head. It is however to be noted that a context can be found in which a scratched head becomes possible:

(35) Creative people are on the whole fragile beings, and letting each other down gently and quietly was the unwritten rule. Sometimes just a blank look or a scratched head was enough to see a candidate quietly pulled down and consigned to the bin. (www-scf.usc.edu/ moyerd/linds_redding.html)

In (35), it is not a single occurrence but the iteration of the occurrence "scratch one's head", i.e. the creation of a type of typical signs which makes a scratched head understandable. Anyone can visualize the candidate doing a stereotyped gesture of powerlessness.

It is much more difficult to conceptualize a learnt lesson as it is the agent who is affected, not the object lesson which does not change whether it is learnt or not. Other examples include ?a devised plan, where a qualification is necessary to make the expression acceptable: a carefully/ cunningly devised plan, a *sratched head (Bolinger [1967: 9]), ${ }^{*}$ a taken cab, ${ }^{*}$ a caught train, ${ }^{*}$ a seen film, ${ }^{*}$ a found solution, ${ }^{*}$ a reached destination, ${ }^{*} a$ handed letter, ${ }^{*}$ a heard voice, ${ }^{*}$ a loved boy, unless loved is modified with an adverb: the most loved boy I knew (USA Today, 1998), a much loved boy. 

written:

(36) During secondary education, the use of the spoken word increases.

(Susan Hinchliff, (ed.). Teaching Clinical Nursing, 1986)

\subsection{The semantics of the verb}

The semantics of the verbs plays an important part in the possibility for V-ED to fill the prenominal slot. A verb with a very general meaning such as say cannot fill the prenominal slot: *a said instruction. On the other hand, the verb shout is an acceptable candidate:

(37) Strike could hear voices through the gloom, shouted instructions and the growl and beep of reversing lorries unloading the carcasses. (USA Today, 2014, COCA)

(38) The night before, they had received whispered instructions to meet later. (USA Today, 2014, COCA)

Shouted and whispered (or other verbs describing the manner of speaking, mumbled, stammered, grumbled, etc.) are more specific than say; they do not appear redundant and can occur in prenominal position.

\subsubsection{Verbs of creation}

Verbs of creation (Ackerman \& Goldberg [1996:19]), also called "constructive accomplishments" (Grimshaw \& Vikner [1993: 146]) belong to the paradigm of make, bake, build, draw, and so on. They are not acceptable as attributive adjectival passive participles: *a built barn. As a barn is necessarily built, it is superfluous to say it (this has been theorized as the "non-redundancy constraint" (Ackerman \& Goldberg [1996: 21])):

the APP [adjectival past participle] must designate a property which is not already implied by the frame semantics associated with the head noun.

However, the non-redundancy constraint does not apply when the object does not necessarily come built in the first place, for example "a built model" or "a built kit", as in the following example:

(39) Restoring a built kit is the next-best choice, depending on the kit's condition and completeness. (George Bojaciuk, Building and Detailing Scale Model Muscle Cars, 1998)

To make the expression built barn acceptable, there has to be a "paradigmatic contrast" [Ackerman \& Goldberg 1996], as in (40), where built barn is contrasted with burnt barn:

(40) In the Amish community what is the difference between a built barn and a burned barn? (www.silosandsmokestacks.org/wp-content/uploads/ 2013/03/microsoft_word__an_amish_barn_raising.pdf)

Another way of making the expression right is to modify V-ED with an adverb:

(41) This was found crawling on lumber inside a recently built barn. (https://bugguide.net/node/view/1589547/bgimage)

(42) The cloth was then passed to a group of twenty or so of us who sat at a

long table in a beautifully built barn. (Rebecca Burgess \& Courtney White, 
Fibershed: Growing a Movement of Farmers, Fashion Activists, and Makers for a New

Textile Economy, 2019)

\begin{abstract}
limiting the scope of the referent of the head noun - and evaluative in (42). The modifiers add specificity to the noun and change the generic meaning of build to a more specific meaning. The focus is not just on the barn (as would be the case with a recent barn or a beautiful barn), but on the resultant state of the building process. possible as an opposition build/natural is implicit or can be made explicit, as in the following example:

(43) Obviously, in terms of logic, there is no way that one can include all forms of built shelter to define architecture, and then move from a natural "shelter" to a massive structure. (David Warburton Architecture, Power, and Religion: Hatshepsut, Amun \& Karnak in Context, 2012)
\end{abstract}

Recently in (41) and beautifully in (42) add distinctive features, temporal in (41)

51

\subsubsection{Verbs of destruction}

Verbs of destruction (annihilate, break, bulldoze, crush, damage, decimate, demolish, destroy, devastate, flatten, overturn, raze, ruin, trash, wreck, etc.) can easily fill a prenominal slot:

(44) When I heard her voice I scanned the area and I expected to see pieces of scattered rubbish and a demolished barn all around me. (Brandon Swarrow, The Barn, 2007)

This is not surprising as the state demolished is the result of an irreversible process and thus completely stabilised. The non-redundancy rule applies as demolish is not one of the semantic features of a barn. The verbs in the list above are transitive or can be used transitively if they are not intrinsically transitive. Intransitive verbs, such as dilapidate, which do not passivize for lack of an agent, can also have an adjectival function: $a$ dilapidated barn. The change from one state to another is gradual as it involves a slow process, and as it refers to a possible "natural" state, the result of neglect, the stabilisation process is viewed as being complete and irreversible. Proof of the adjectival features of dilapidated is that this word can be coordinated with a central adjective such as old:

(45) As she did so, she noticed that the heath adjoining the road rose up to a small hill, on top of which stood an old and dilapidated windmill. (Robert Moss, The Challenge Book of Brownie Stories, 1988, BNC)

Another factor contributing to the adjectival features of dilapidated is that the verb dilapidate (with the meaning 'to fall or cause to fall into ruin or decay', Collins English Dictionary) is rarely used in present-day English. Other examples of an adjectival use of an intransitive verb include a much-travelled woman, a much-travelled road, a confessed killer, a practiced pianist, an experienced mountaineer, a versed and practiced maritime professional. 


\subsubsection{Ergative verbs}

With ergative verbs (termed "unaccusative predicates" by Ackerman \& Goldberg [1996: 19]), the resultant state, obtained independently from any agentive source, also has a high degree of stability, for example a frozen river, or melted ice:

(46) Three of the meteorites were found on rocky terrain where they may have fallen directly or been deposited by melted ice. (New Scientist, BNC)

In the transitive use (melted chocolate), the process is recoverable ("someone melted the chocolate"); when the process is "natural", the resulting state is totally detached from the process. Melting ice is not ice, nor is it water. With faded, the process fade has reached a final stage. The resultant state is therefore stable, which is not the case with V-ING, where the process has not reached its stabilised stage:

(47) The documents, which were handwritten in fading ink (Greg Cox, The Librarians and the Lost Lamp, 2017, COCA])

The semantics of ergative verbs indicates a change of state, so the stress is placed on the resultant state, and the change is encoded as desirable or, on the contrary, adversative (which is the most frequent case in the COCA and BNC). It can further be encoded as irreversible (fallen leaves), and this feature facilitates the adjectival conversion. The same phenomenon can be observed with fallen in collocation with soldier with the meaning 'dead', for instance in the following title:

(48) "The Cult of the Fallen Soldiers in Germany." (GL Mosse, Journal of Contemporary History, Vol. 14, No. 1, Jan. 1979)

When the process is reversible or temporary, then the V-ED + N construction is not attested $-{ }^{*}$ a fallen tiger:

(49) The tiger fell in the snow. It got up and shook its head. (Caleb Scott Prentiss, Zipharus Chronicles: the Crystal of Axiom, 2009)

As illustrated above, the stative interpretation relies in part on a cultural construal and perception of the world. We know from experience that a tiger can get up after having fallen when a leaf cannot. Where fallen soldier is a euphemism for dead, with a fallen woman, the question of whether the woman can be rehabilitated is not the point. In the corpus, the collocation is culturally marked and refers to what appears as an unchangeable condition.

\subsubsection{Resultative constructions}

With resultatives of the form $\mathrm{V}_{\text {ergative }}+\mathrm{ADJ}$, as in (50) below, an attributive use of $\mathrm{V}$-ED is not acceptable:

(50) The dream by itself would have been a trifle, but while she was dreaming the window of the nursery blew open, and a boy did drop on the floor. (James M. Barrie, Peter and Wendy, 1911)

Such verbs induce a sudden change of state, and thus the unacceptability of $* a$ blown open door. The object, namely a window in (50), has not incurred any change; the focus is placed on the action of blowing the window open, not on the window itself. 
Furthermore, this process happens once, so being blown open is not a property of the door. On the contrary, with a resultative construction involving a transitive verb, for example to paint a door red, the state of the door is different once the action has ended. A permanent resultant state can be construed:

(51) Big metallic lock hanging on a red painted door. (www.shutterstock.com/fr/search/red\%2Bpainted\%2Bdoor?page=4)

\subsubsection{Prepositional phrases and phrasal verbs}

61

When a locative prepositional phrase is an adjunct to a verb, V-ED cannot occur in an attributive position:

(52) Then she jumped over the hedge, like a hunter, into the next field.

(W. Jenkyn Thomas, The Welsh Fairy Book, 1907)

From the sentence she jumped over the hedge, a "V-ED + N" structure is not licenced: *A jumped over hedge. The object refers to a position in space and is consequently not affected by the event denoted by the verb. Even if the object is affected in some way, a past participle of a prepositional verb cannot be used in attributive position $\left({ }^{*} a\right.$ kicked at door). Only prepositional verbs such as looked after can be used attributively:

(53) A child who has been in the care of their local authority for more than 24 hours is known as a looked after child. Looked after children are also often referred to as children in care, a term which many children and young people prefer. (https://learning.nspcc.org.uk/children-and-families-atrisk/)

Transitive phrasal verbs (hand in, knock down) are submitted to the same constraints (non-redundancy, affectedness) as simple verbs: *handed-in essays does not answer any communicative needs, whereas in knocked-down buildings, the end-state is visible, the change irreversible:

(54) The reason is that when it comes to training for a building collapse, there's just nothing like a knocked-down building, and those can be hard to find. (http://vaildaily.com)

64 A locative prepositional phrase, however, does not undergo any change of state so there is no transition between two states and consequently no end-state, unless the noun is sufficiently differentiated by a characteristic feature common to a whole subclass (a looked after child in (53)). The possibility of preposing a V-ED is context sensitive. This is what we will be looking at in the next section.

\subsection{Facilitating contexts}

At discourse level, a facilitation process (i.e. a text that "breaks a path" to the form considered) makes comprehension of an occurrence of V-ED in attributive position more immediate. For instance, in (55), the association between insulted and goddess is prepared by the explanation given in the context before, "rejects the lustful invitations of Venus": 
(55) Its roots are in Shakespeare's early poems Venus and Adonis and The Rape of Lucrece. Adonis, cold and puritanical, rejects the lustful invitations of Venus, the supreme goddess, He goes off hunting, and as a punishment for his presumptuous chastity, is killed by a boar. This avenging boar, the agent of the insulted goddess, is henceforth identified with the destructive forces that produce tragedy. (The Daily Telegraph, 1992) otherwise unusual V-ED $+\mathrm{N}$ collocations. Below, two such contexts are examined: specialised contexts, captions and titles.

\subsubsection{Specialised contexts}

Specialised contexts occur in scientific or technical discourse characterised, roughly speaking, by a higher degree of monoreferentiality and precision (Gotti [2003]) than in general language. Following Gotti, Grygiel [2017:4] adds: "monoreferentiality means that there is one word form used for one referent and its exact sense can be inferred without reference to the context". Our hypothesis is that in specialised contexts V-EDs are stabilised in adjectival forms as they are endowed with a technical meaning whose definition needs to be stable.

For example, the association of taught and course seems unlikely as a course is necessarily taught. It is however a possible and meaningful expression in the context of universities. In (56), taught course refers to a subclass of courses and is opposed to a "degree by research" (and not to an untaught course which would carry a negative connotation):

(56) One of the key differences between postgraduate programmes is whether you choose to do a taught course, or study for a degree by research. (https://gradireland.com/further-study/advice-and-funding/ advice/research-vs-taught)

In the same way, expressions which would seem odd, like "a looked after child", are made acceptable in a technical language (see example 53 above). Many collocations used in specialised English have become lexicalized: restricted area, signed copy, inbuilt engine, used car, knocked down house (an assembled house in the US), sealed ball bearing, heated bearing, tapered roller, etc.

\subsubsection{Captions and titles of paintings and photographs}

When captions or titles of paintings or photographs describe a static scene, a landscape for instance, V-EDs easily occur in pre-nominal position. The text is an explanation of what one can see in the picture. It is therefore not necessary to construct a relation between the V-ED form and the noun it describes. Occurrences of "V-ED N" that would not normally be possible can become acceptable when in captions. For example, fallen describing an animate object:

(57) "Mountain landscape with a fallen donkey" (Hans III Momper Ios de Jordaens)

In this case, it is the painting which is static; its title describes a scene which appears to be "frozen"; the donkey is lying on the ground. It might well be a temporary situation, but for the viewer, it is a state that has no temporal boundaries. 
In the following examples, "destroyed" becomes a descriptive quality in (58) and "a cut field" is easily conceivable in (59) (the participle usually appears in a negative form, uncut):

(58) This photo shows the destroyed house of Angela and Brad Frase after an explosion in Sterling. (www.washingtontimes.com/multimedia/image/ ap_house_explosion_racial_slurs_27698jpg/)

(59) A single hay bale on a cut field under a cloudy sky; Ravensworth, North Yorkshire, England. (www.pictorem.com)

71 A caption or title can even allow the use in attributive position of a verb (sleep in the example below) whose object is in a prepositional phrase (in [a] bed):

(60) Low angle view of a slept-in bed with a messy sheet, no blankets, in a blue and white bedroom home design. (stock.adobe.com/fr/images/lowangle-view-of-a-slept-in-bed-with-a-messy-sheet-no-blankets-in-a-blue-andwhite-bedroom-home-design/272191662)

72 In the titles of articles or books as well, the constraint of brevity may allow the use of an otherwise hardly acceptable "V-ED + N" construction. The article then provides the context which helps remove any ambiguity as to the interpretation of V-ED + N:

(61) How to Raise a Fallen Horse. We have seen it recommended by a gentleman who has had much experience in the matter, that when a horse has fallen from the slippery state of the ground, the readiest method of enabling him to rise is to put an old rug or carpet under his fore feet [...] (Scientific American, 1858)

In the same manner, a description, a scene discovered by a narrator makes a favouring context for a stative interpretation of passive forms - which can then be identified as "statal passives" [Palmer 1968]:

(62) I left the bathroom and went into the big room again. Carlisle's shirt, tie, and jacket were thrown over the wooden chair. His shoes were on the floor under the chair, and his socks were balled inside the shoes. Stephanie's dress and underwear were heaped on the seat of the chair. (Ed McBain, Vanishing Ladies, 1961)

The verbs throw, ball and heap are verbs of activity, implicating a change of state. In (62), it is the result of the activity denoted by the verb which is discovered through the eyes of the narrator.

\subsection{Adjectives derived from other adjectives}

74 A few adjectives have V-ED counterparts: open/opened; yellow/yellowed (and all colour adjectives):

(63) Talbot thanked him, rose, washed the sleep from his face and eyes and made his way to the admiral's quarters. A shirt sleeved Hawkins beckoned him to join himself and Montgomery at the breakfast table. [...] Van Gelder knocked on the opened door and entered, a message slip in his hand. (Alistair MacLean, Santorini, 1987, https://arounddate.com/santorini-byalistair-maclean/) 
(64) [...] she was bold enough to tip-toe towards the drawing room where she hesitated again and peered round the door. [...] She knocked on the open door and Mr Browning came through from the other room. (Margaret Forster, Lady's Maid, 1990, BNC)

(65) Apples of many shades of yellow and red, brown and gold were laid out on yellowed newspaper, line after line, row upon row, on broad slatted shelves. (Rachel Anderson, Paper Faces, 1991, BNC)

The difference between open and opened is not as clear-cut as that between yellow and yellowed. A door has to go through a process to be in an "open" state and unless open has the meaning 'making an opening' ("a newly opened door"), where the resultant state is not opposed to "closed" as in a door being open or closed, agentivity is implicit in both close and closed. Yellowed, on the other hand, expresses a (negative) process. The verb is intransitive and although no agentivity is present, there is a cause responsible for the gradual change of state.

The end result is the same. A paper is usually white by default. With yellow paper, the state yellow has no relation to a previous state. With yellowed, the state is reached after a transformation and follows from a previous state. There are here two degrees of stabilisation, which can be defined by their relation or not to another state. It is the same with other central adjectives (hot, cool for example). In (66), the head noun is a device; it is important to mention the process, not just the end-state:

(66) Heated and cooled seats are available on the Reserve model. (The Detroit News, 2017, COCA)

The same goes for all doublets: dry/dried, and all derived verbs from adjectives which in their turn generate past participles with an adjective value - damp/dampened; soft/ soften; red/redden. This implies that they keep some of the processual value of the verb.

\subsection{Two past participles}

Some verbs have dual forms in the past participle, for instance rotted and rotten:

(67) The house, a shingled box, had a sunken porch, a rotted roof, and windows shot out by teens with BB guns. (Stephanie Gayle, Idyll Threats: a Thomas Lynch Novel, 2016, COCA)

(68) It seemed to have fallen into disrepair overnight, peeling paint, rotten roof, rusted gutters. (Ruth Moose, Doing it at the Dixie Dew, 2014)

It would be tempting to say that rotten corresponds to a state cut off from the process leading to it and rotted implies a resultant state, with an underlying process. The corpus, however, does not show any clear difference between the two forms, no more than between lighted and lit (even though each form has some specialised uses, for example sun-lit). The verb bereave also has two participles: bereft means dispossessed, bereaved refers to the loss of relatives (OED).

\subsection{V-ED in passive constructions}

V-EDs in passive constructions are sometimes referred to as verbal passive participles (Lundquist [2013]). This terminology will be adopted here. In a long passive (with a by prepositional phrase), a stative value is incompatible with the mention of an agent: 
(69) About 59 percent of the 130 women surveyed were hired by smaller companies when they returned to work. (Atlanta Journal Constitution, 2005, COCA) agentive and no underlying process can be retrieved:

(73) There was a house surrounded by tall elms that looked as though it might be a Queen Anne. (Roald Dahl, "Parson's Pleasure", 1960)

(74) Peter looked round the Bishop's study, which was entirely lined with books. (Joanna Trollope, The Rector's Wife, 1992, BNC)

There is a simple mention of the existence of house and elms and study and books which can be shown in the following paraphrase: there were tall elms around it and there were lines of books. The prepositional phrases are mandatory complements, as there cannot be a default interpretation as in His army was surrounded, where the agent need not be specified to be understood.
(75) It was hard work, and it took several minutes before he had the whole thing more or less smashed to pieces. (Roald Dahl, "Parson's Pleasure", 1960) (76) There was a slight pause. He had his hands clasped high in front of him, level with his chest, and he was rubbing one palm against the other, making a soft scraping noise. (Roald Dahl, "Parson's Pleasure", 1960)

The resultant states, "smashed" and "clasped", are located relative to the agent "he" by the locator have. The underlying process is not activated as it would be in "he had smashed the whole thing more or less to pieces" or "He had clasped his hands". For 
(76) another rewording could be: "his hands were in a certain position - they were clasped".

Palmer [1968: 89] recognizes that even with statal passives, there are "degrees of adjectiveness" (with "married" in "they are married and happy" which has "some adjectival functions" and verbs such as "defeated" and "killed" which do not satisfy all the requirements of a typical adjective).

\section{Summary of the results}

Table 1 below summarises the observations made in this article and indicates the degree of "adjectiveness" based on the criteria defined by Quirk et al [1985: 404] and Huddleston \& Pullum [2002:528] to identify a typical adjective: the possibility of appearing in attributive, predicative and postpositive functions, of being gradable, premodified by very or adverbs such as remarkably or surprisingly, and lastly of being used as a comparative or superlative.

The letter in each column refers to a specific function. The number obtained in the column "Adjective qualities" is only indicative and is intended to give an idea of the more or less complete inclusion of a V-ED form in the class of adjectives. As has been shown in the article, there are differences in the adjective quality of the V-ED forms according not only to the semantics of the verb, but also to the nature of the subject and the object and context. These complex interactions are difficult to quantify.

The column which gives the most important information about the adjectival status of V-EDs is (a): the possibility of having V-ED in attributive position. In predicative function, V-ED is often part of a passive construction. The absence of an agent will add to a potential adjectival interpretation.

Table 1: Degree of "adjectiveness" of V-EDs

\begin{tabular}{|c|c|c|c|c|c|c|c|c|}
\hline & $\begin{array}{l}\text { (a) } \\
\text { attributive }\end{array}$ & $\begin{array}{l}\text { (b) } \\
\text { predicative }\end{array}$ & $\begin{array}{l}\text { (c) } \\
\text { postpositive }\end{array}$ & \begin{tabular}{|l|} 
(d) \\
gradable \\
(for \\
instance \\
premodified \\
by very)
\end{tabular} & $\begin{array}{l}\text { (e) } \\
\text { premodified } \\
\text { by such } \\
\text { adverbs as } \\
\text { remarkably, } \\
\text { surprisingly }\end{array}$ & $\begin{array}{l}\text { (f) } \\
\text { Comparative / } \\
\text { superlative }\end{array}$ & $\begin{array}{l}\text { Adjective } \\
\text { qualities }\end{array}$ & Example \\
\hline HAVE V-ED & - & - & - & - & - & - & 0 & $\begin{array}{ll}\text { He } & \text { had } \\
\text { clasped } & \text { his } \\
\text { hands. } & \end{array}$ \\
\hline
\end{tabular}




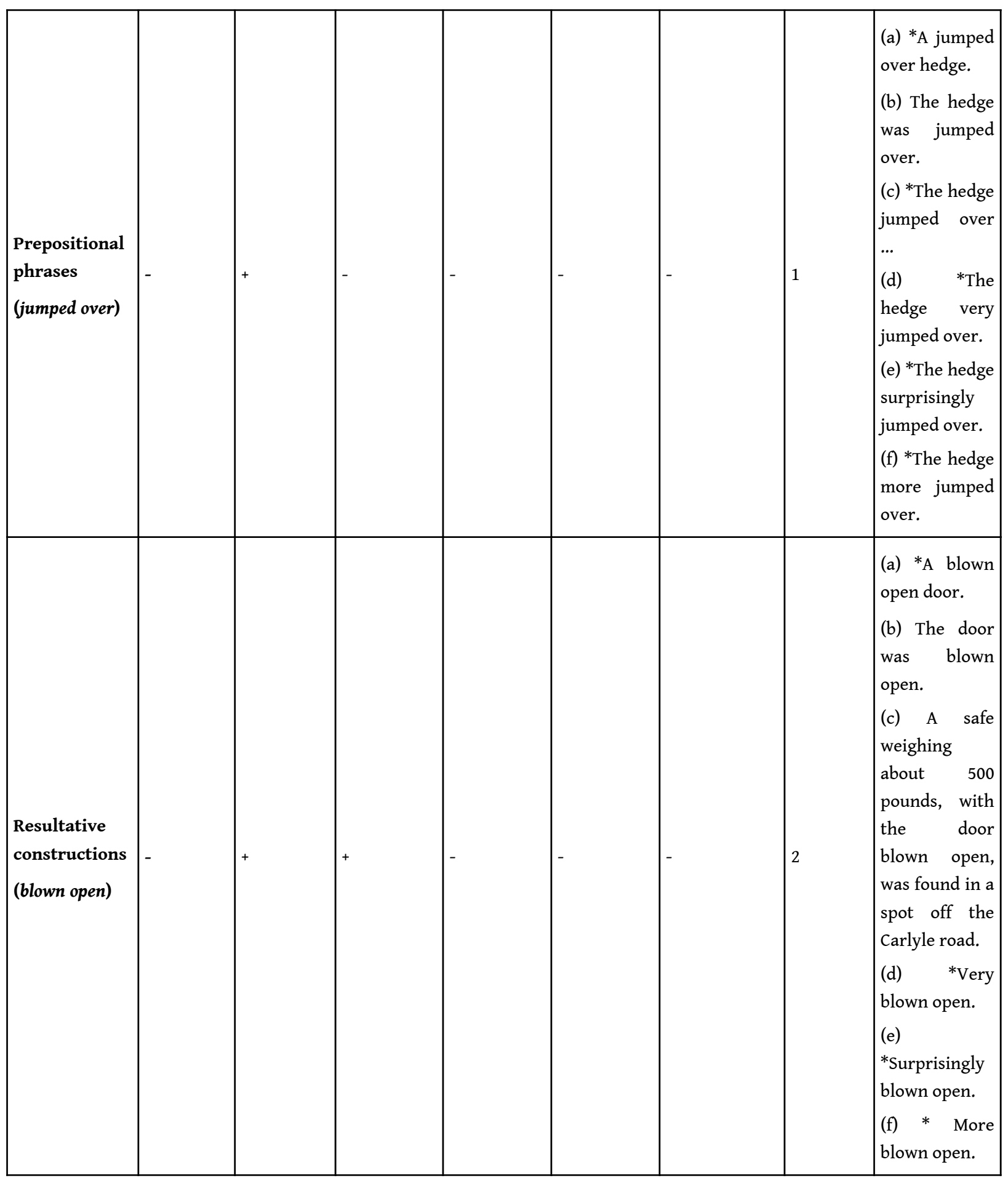




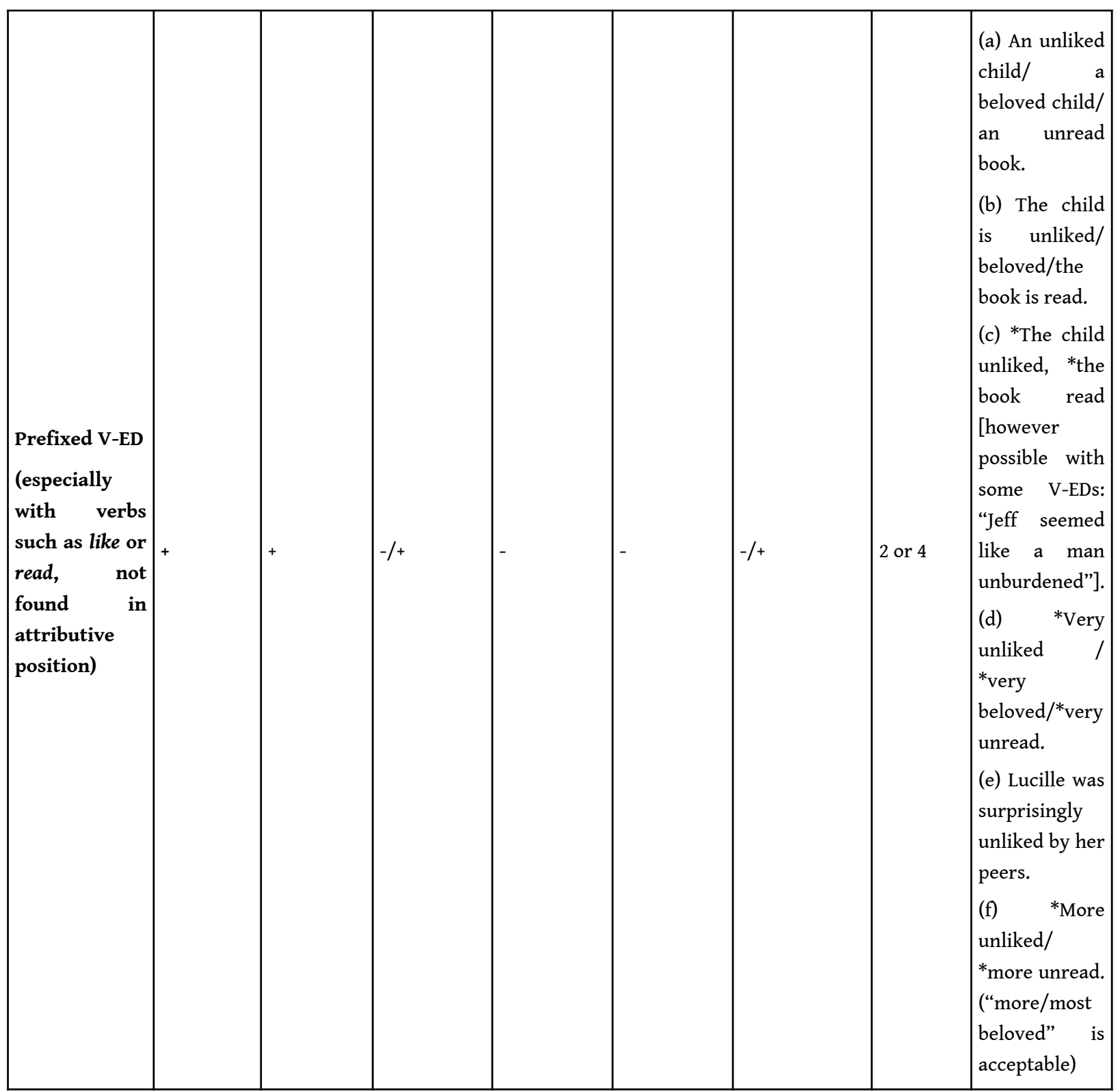




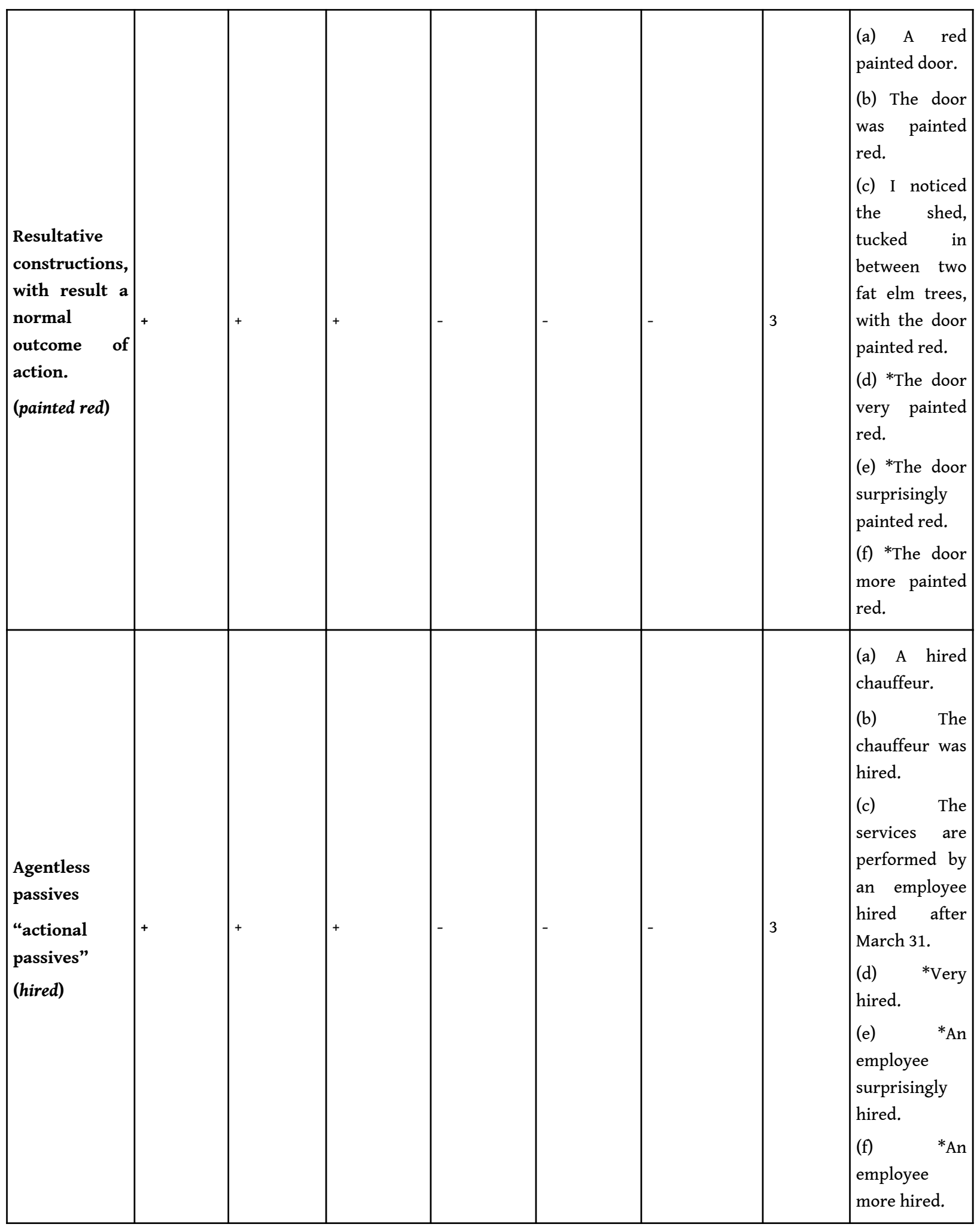




\begin{tabular}{|c|c|c|c|c|c|c|c|c|}
\hline $\begin{array}{l} \\
\text { V-ED } \\
\mathrm{V}=\text { stative } \\
\text { verb (situate) }\end{array}$ & - & + & + & - & . & - & 3 & $\begin{array}{l}\text { (a) *A situated } \\
\text { home. } \\
\text { (b) The home } \\
\text { is situated in } \\
\text { the Old Town. } \\
\text { (c) A home } \\
\text { situated in the } \\
\text { old Town. } \\
\text { (d) *A very } \\
\text { situated } \\
\text { home. } \\
\text { (e) } \\
\text { remarkably } \\
\text { situated } \\
\text { home. } \\
\text { (f) }{ }^{*} \text { Most } \\
\text { situated. }\end{array}$ \\
\hline $\begin{array}{ll} & \\
& \\
& \\
\text { V-ED } & \\
\text { Verbs } & \text { of } \\
\text { creation }+ & \mathrm{N} \\
\text { referring } & \text { to } \\
\text { object created } \\
\text { (built) }\end{array}$ & - & + & $1+$ & + & |- & - & 3 & 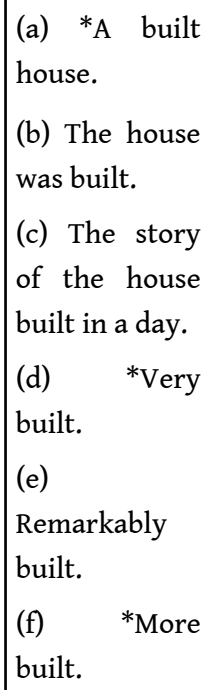 \\
\hline
\end{tabular}




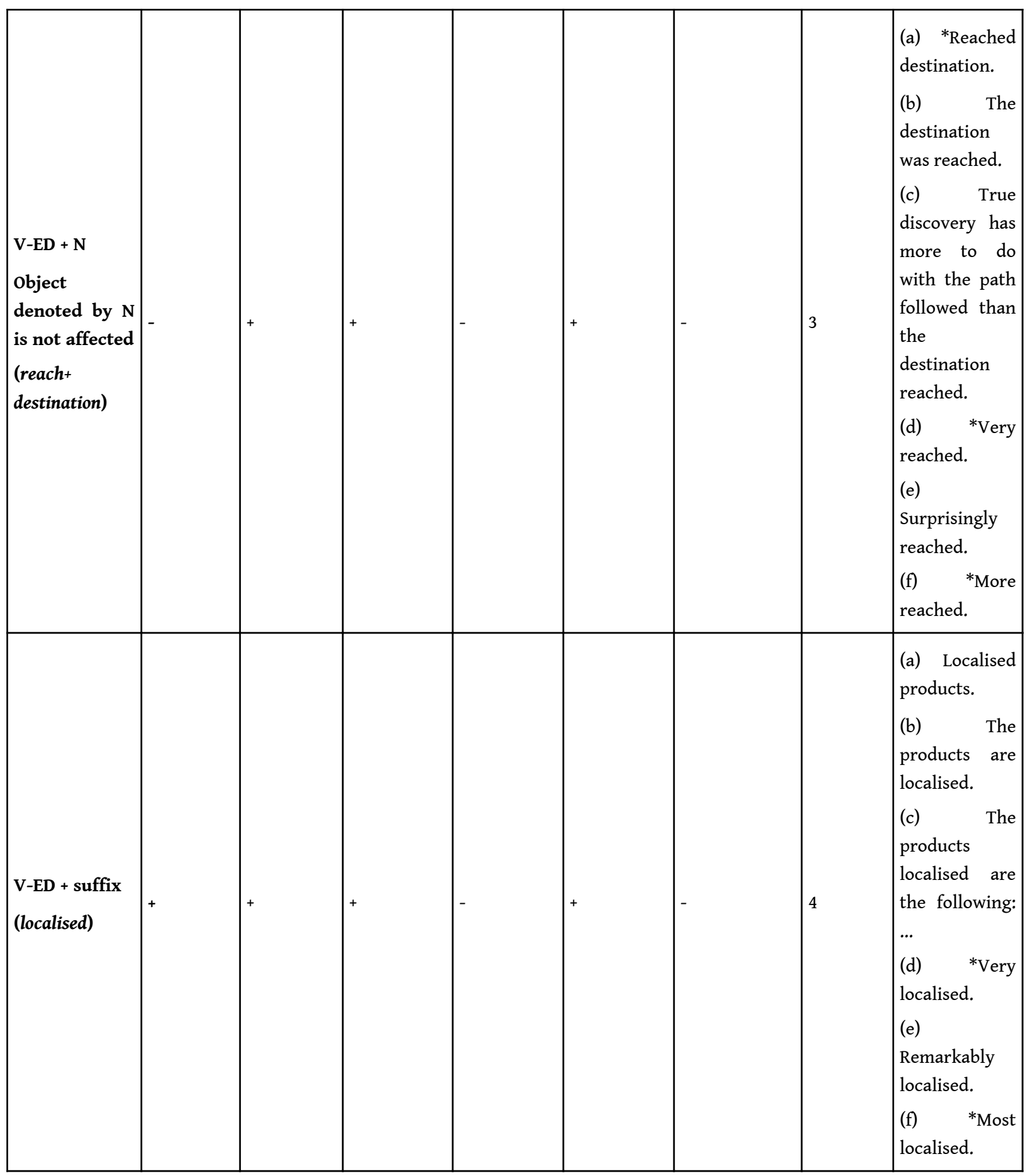




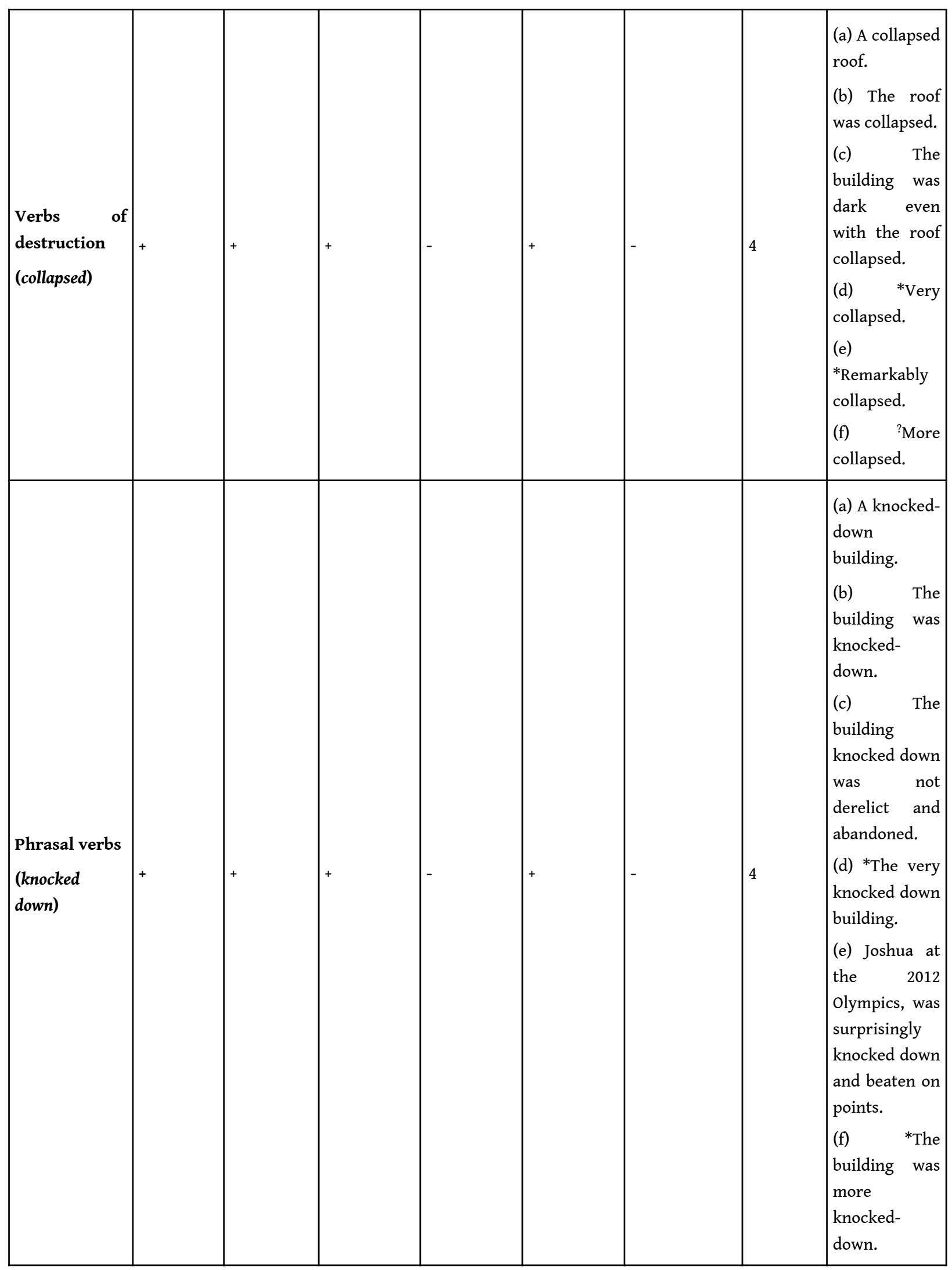




\begin{tabular}{|l|l|l|l|l|}
\hline & & & & \\
Ergative \\
verbs \\
(melted)
\end{tabular}




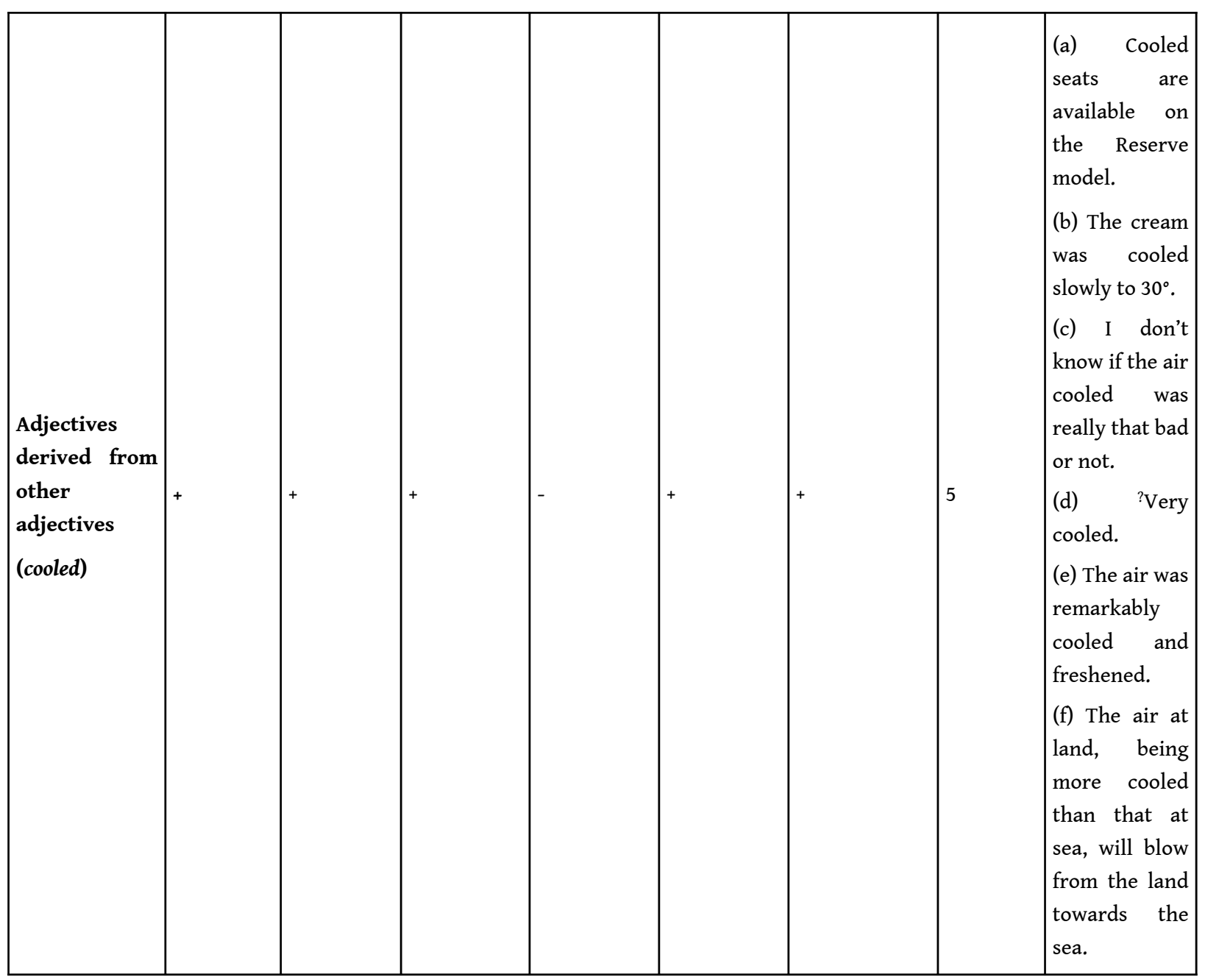




\begin{tabular}{|c|c|c|c|c|c|c|c|c|}
\hline $\begin{array}{lr}\text { V-ED } & \text { with } \\
\text { change } & \text { of } \\
\text { state verbs } & \\
\text { (fold) } & \end{array}$ & + & + & $1^{+}$ & + & $1^{+}$ & + & 6 & 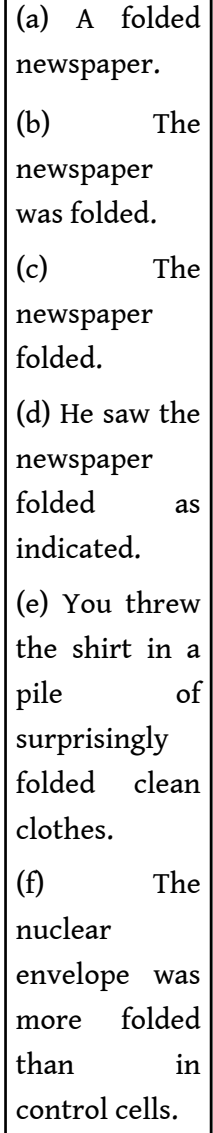 \\
\hline
\end{tabular}




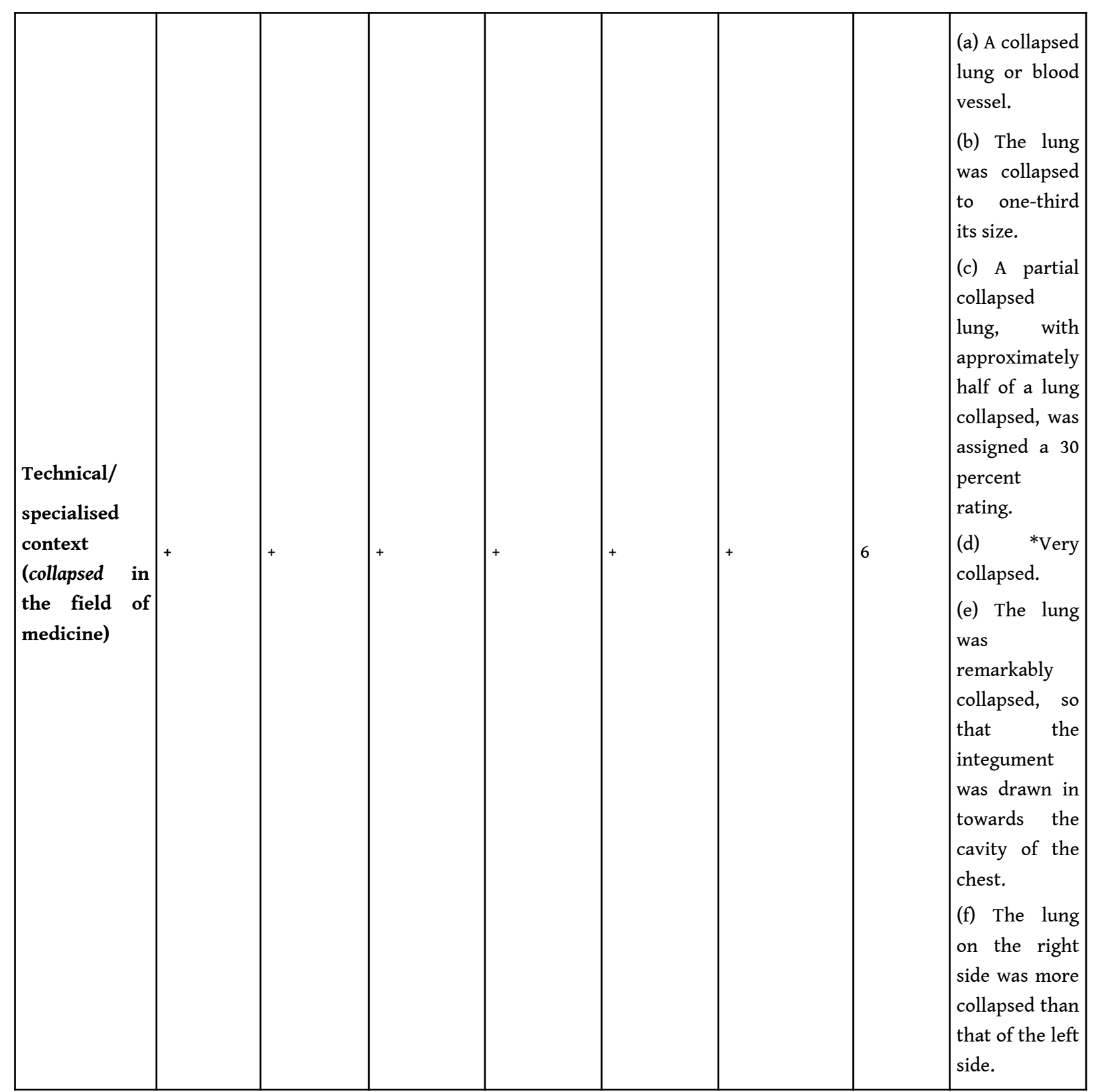




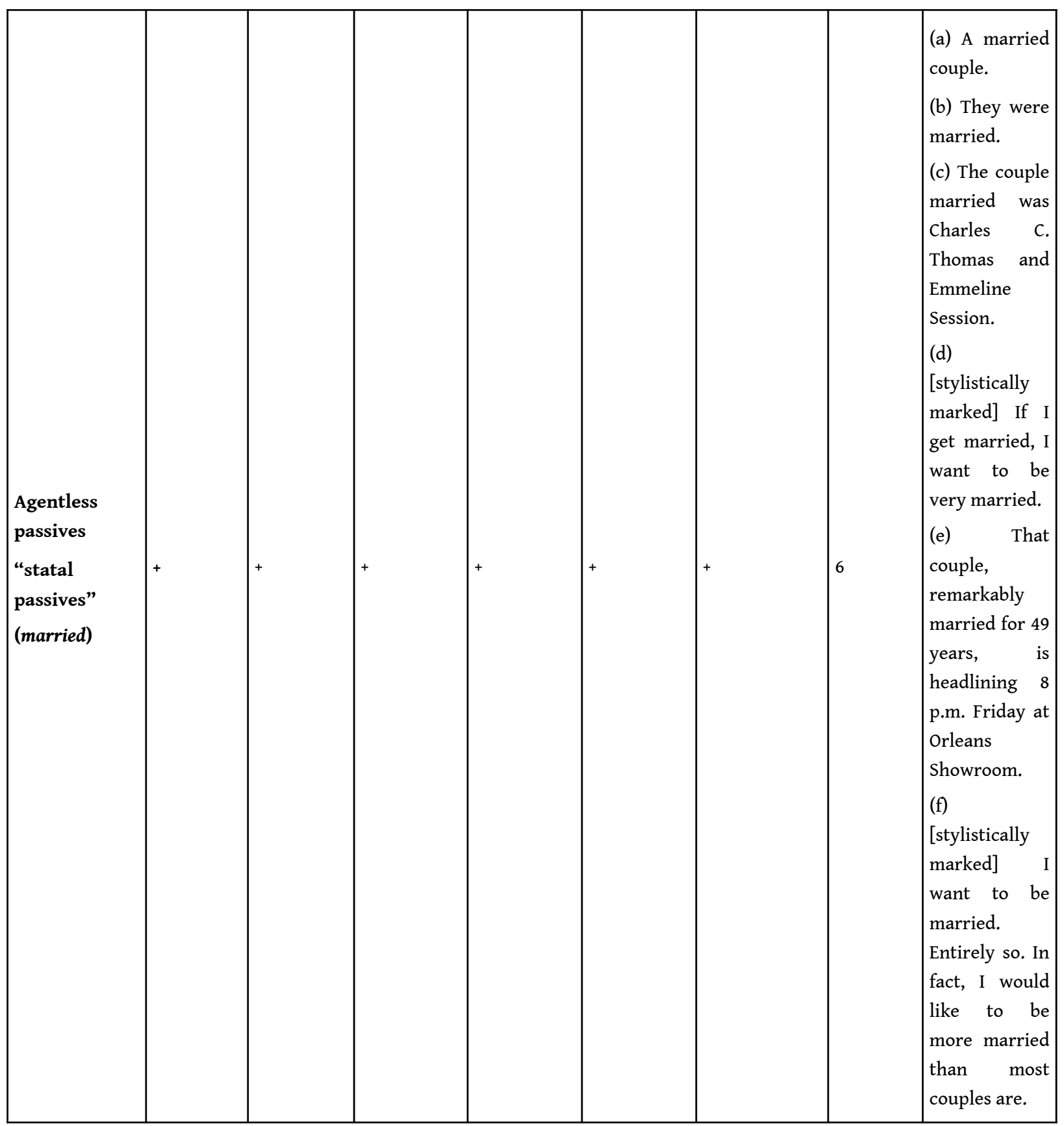




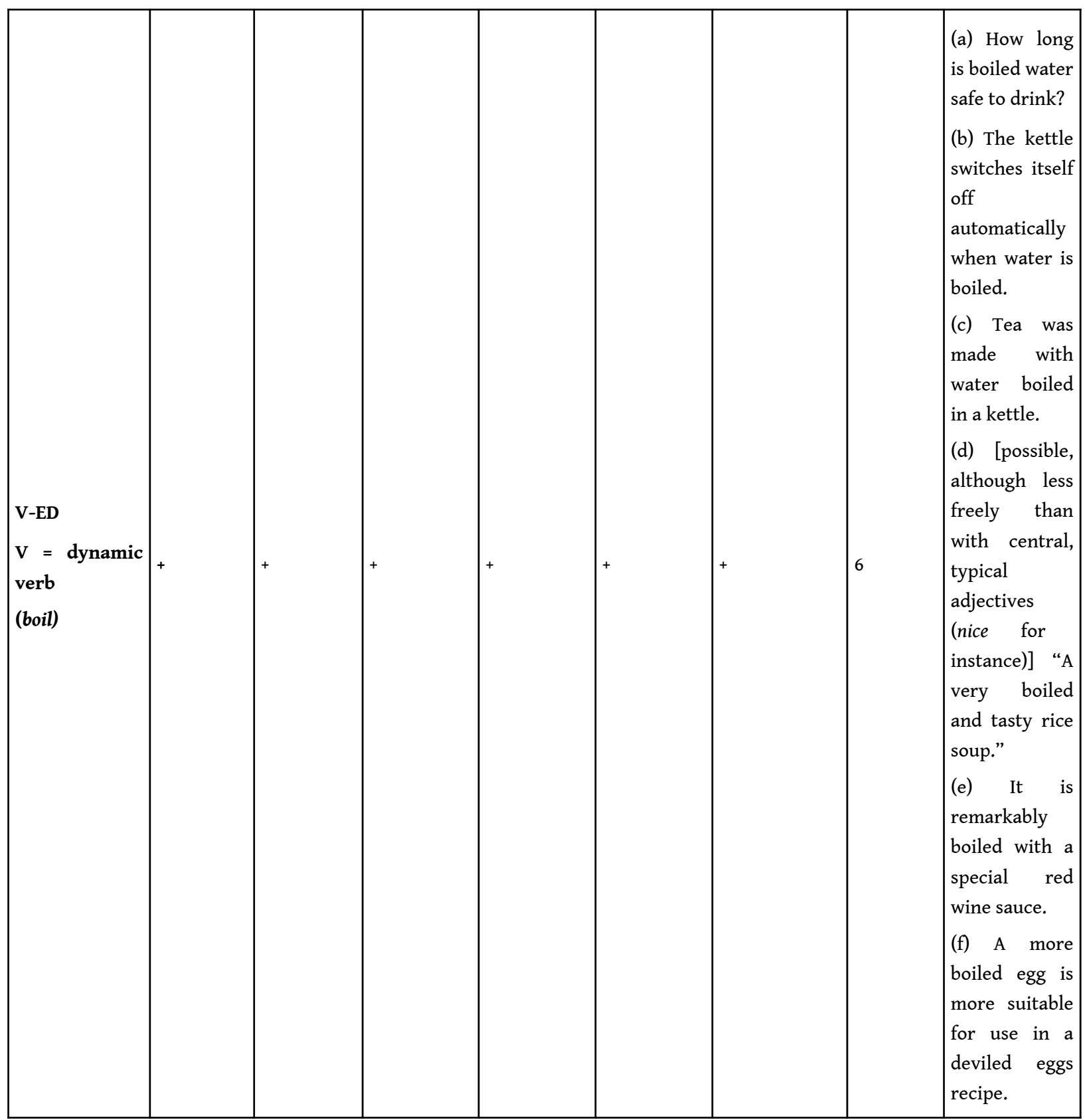

In Table 2, the context or the structure of the examples provides the adjectival interpretation. The only criterion is the possibility for V-ED of having an attributive function, therefore the criteria used in Table 1 are irrelevant as there is no possibility of variation.

Table 2: Degree of "adjectiveness" of V-EDs based on context or structure

\begin{tabular}{|l|l|l|}
\hline & Attributive & Example \\
\hline
\end{tabular}




\begin{tabular}{|l|l|l|}
\hline $\begin{array}{l}\text { Captions and } \\
\text { titles }\end{array}$ & + & $\begin{array}{l}\text { Mountain landscape with a fallen donkey. } \\
\text { Collapsed Flybe tells passengers not to travel to airports. } \\
\text { [In this example, a metaphorical use may also be a contributing } \\
\text { factor to an attributive use of V-ED }]\end{array}$ \\
\hline HAVE N V-ED & + & He had his hands clenched. \\
\hline
\end{tabular}

\section{Conclusion}

\section{BIBLIOGRAPHY}

ACKERMAN Farrell \& GOLDBERG Adele E., 1996, "Constraints on adjectival past participles", in GOLDBERG Adele E. (Ed.), Conceptual Structure, Discourse, and Language, Stanford, CA: CSLI Publications, 17-30.

ACKERMAN Farrell \& GOLDBERG Adele E., 2001, “The Pragmatics of Obligatory Adjuncts”, Language, 77 (4), 798-814.

BOLINGER Dwight, 1967, “Adjectives in English: Attribution and Predication”, Lingua 18, 1-34. 
BOLINGER Dwight, 1972, Degree Words, The Hague: Mouton.

BRUENING Benjamin, 2014, "Word formation is syntactic: adjectival passives in English", Natural Language \& Linguistic Theory, 32 (2), 363-422.

DAVIES Mark, 2004-, British National Corpus (from Oxford University Press). Available online at https://www.english-corpora.org/bnc/

DAVIES Mark, 2008-, The Corpus of Contemporary American English (COCA): 560 million words, 1990present. Available online at https://www.english-corpora.org/coca/

DAVIES Mark, 2010-, The Corpus of Historical American English (COHA): 400 million words, 1810-2009. Available online at https://www.english-corpora.org/coha/

GIVón Talmy, 1970, "Notes on the Semantic Structure of English Adjectives”, Language, 46 (4), 816-837.

GOTTI Maurizio, 2003, Specialized Discourse: Linguistic Features and Changing Conventions, Bern: Peter Lang.

GRIMSHAW Jane \& VIKNER Sten, 1993, “Obligatory Adjuncts and the Structure of Events", in REULAND Eric \& ABRAHAM Werner (eds), Knowledge and Language, Dordrecht: Kluwer Academic Publishers, 143-155.

GRYGIEL Marcin, 2017, "Specialist Languages and Cognitive Linguistics: A Marriage of Convenience or Irreconcilable Opposites?”, in GRYGIEL Marcin (Ed.), Cognitive Approaches to Specialist Languages, Newcastle upon Tyne: Cambridge Scholars Publishing.

HUDDLESTON Rodney \& PULLUM Geoffrey K., 2002, The Cambridge Grammar of the English Language, Cambridge: Cambridge University Press.

KIBORT Anna, 2005, “The Ins and Outs of the Participle-Adjective Conversion Rule”, in BUTT Miriam \& HOLLOWAY KING Tracy (Eds.), Proceedings of the LFG05 Conference, University of Bergen: CSLI Publications, available at http://citeseerx.ist.psu.edu/viewdoc/download? doi=10.1.1.301.486\&rep=rep1\&type=pdf

KRATZER Angelika, 2000, "Building Statives", in JonATHAN Lisa J. et al. (Eds.), Proceedings of the TwentySixth Annual Meeting of the Berkeley Linguistics Society: General Session and Parasession on Aspect, Berkeley: Berkeley Linguistics Society, 385-399. Available at https://semanticsarchive.net/ Archive/GI5MmI0M/kratzer.building.statives.pdf

LEVIN Beth \& RAPPAPORT Malka, 1986, "The formation of adjectival passives", Linguistic Inquiry 17 (4), 623-661.

LUNDQUIST Björn, 2013, “The category of participles”, in IORDACHIOAIA Gianina, ROY Isabelle \& TAKAMINE Kaori (Eds.), Categorization and Category Change, Newcastle: Cambridge Scholars Publishing, 11-32.

MCINTYRE Andrew, 2013, "Adjectival passives and adjectival participles in English", in ALEXIADOU Artemis \& SCHÄFER Florian (Eds.), Non-Canonical Passives, Amsterdam: John Benjamins, 21-41.

OLTRA-MASSUET Isabel, 2014, Deverbal Adjectives at the Interface: A Crosslinguistic Investigation into the Morphology, Syntax and Semantics of -ble, Berlin: De Gruyter Mouton.

PALMER Frank R., 1968 (1965), A Linguistic Study of the English Verb, London: Longman.

PARSONS Terence, 1990, Events in the Semantics of English: A Study in Subatomic Semantics. Cambridge, Mass.: MIT Press. 
QUIRK Randolph, GREENBAUM Sidney, LEECH Geoffrey \& SVARTVIK Jan, 1985, A Comprehensive Grammar of the English Language, London: Longman.

WASOW Thomas, 1977, "Transformations and the lexicon", in CULICOVER Peter, WASOW Thomas \& BRESNAN Joan (Eds.), Formal Syntax, New York: Academic Press, 327-360.

\section{NOTES}

1. I wish to express my gratitude to the two anonymous reviewers whose constructive comments helped me improve this article. Many thanks too to Robert Butler (Université de Lorraine, Nancy) for his helpful suggestions and to Jeni Peake and Catherine Moreau (Université Bordeaux Montaigne) for their review of the final script.

2. The Oxford English Dictionary (online edition) gives the following definition: “(...) an adjective formed from a verb, usually, though not necessarily, constituting an inflection, and typically closely related to the source verb in meaning; spec. a participle or participial adjective."

3. Parsons [1990] makes a distinction between "target states" (reversible, transitory) and "resultant states" (irreversible, "holds forever after"). Various authors have taken up this terminology (among others, Kratzer [2000]).

4. Source: Oxford English Dictionary, online edition.

5. "A human agent is not necessarily a true agent. A sentence like I was much stunned by my friends is acceptable to the extent that by my friends is not a true agent but an agent of result: 'I was much stunned as a result of my friends' being there, as a result of something they did', etc." [Bolinger 1972: 201]

\section{ABSTRACTS}

Among the different ways an adjective can be formed, one of them is the use of the past participle of a verb, as in, for instance: The house was tucked far back from the main road. This process is not a straightforward case of derivation: an ambiguity often remains as to the status of the V-ED form, between adjective and verb, especially with adjectival passives. The aim of this article is to show how verbs can be "stabilised" into adjectives. With excited in they were excited, the stabilisation is complete, whereas with locked in the door was locked, the deriving verb can be reactivated, as in the door was suddenly locked. The parameters surveyed are: the semantics of the verb, agentivity (recoverable or not), prefixing (for instance the prefix be- in bedecked or the negative prefix un- in unchecked), lexicalization (particularly the contribution of the noun in a collocation of the type abandoned child) and, finally, syntax (attributive or predicative position). The conclusion which is reached is that instability is inherent to the use of V-ED adjectives as any variation (the presence of an adverb for example) can change their interpretation. The process of stabilisation is seen as linked to two major parameters: the suppression of the origin of the potential change of state and the backgrounding of agentivity.

Parmi les différentes manières de former un adjectif, l'une d'entre elles est le recours à un verbe au participe passé, comme dans, par exemple, The house was tucked far back from the main road. Ce processus n'est pas un cas classique de dérivation : une ambiguïté souvent demeure quant au 
statut de ces formes en V-ED, oscillant entre verbe et adjectif. Le but de cet article est de montrer de quelle façon les verbes peuvent être «stabilisés " pour devenir des adjectifs. Avec excited dans they were excited, la stabilisation est complète, alors qu'avec locked dans the door was locked, le verbe dérivant peut être réactivé, comme dans the door was suddenly locked. Les paramètres étudiés sont: la sémantique du verbe, l'agentivité (récupérable ou pas), la présence de préfixes (par exemple le préfixe be- dans bedecked ou le préfixe négatif un-dans unchecked), la lexicalisation (et plus particulièrement la contribution du nom à une collocation de type abandoned child) et enfin la syntaxe (position épithète ou attribut). La conclusion est que l'instabilité est inhérente à l'emploi d'adjectifs en V-ED car toute variation (la présence d'un adverbe par exemple) peut changer leur interprétation. Le processus de stabilisation est considéré comme étant lié à deux paramètres majeurs: la suppression de l'origine du changement potentiel et la mise en arrière-plan de l'agentivité.

\section{INDEX}

Mots-clés: participe passé, participes adjectifs, dérivation, agentivité, passif, stabilisation référentielle

Keywords: past participle, participial adjectives, derivation, agentivity, passive, referential stabilisation

\section{AUTHOR}

JEAN ALBRESPIT

Université Bordeaux Montaigne

jean.albrespit@u-bordeaux-montaigne.fr 